\title{
What the elderly think of the care provided by health services
}

Juliana Almeida Marques Lubenow' (D) Antonia Oliveira Silva' ${ }^{\mathbb{D}}$

\section{Abstract}

Objective: To identify the social representations of the elderly on the care provided in health services. Method: An exploratory study with a qualitative approach was carried out, in which 238 elderly persons were interviewed about the care they received in Basic Health Units and in a center of specialized care. Their discourse was recorded and transcribed in its entirety, and processed using Iramuteq software. The results were discussed using Social Representation Theory. Results: The elderly associated good care with being treated with respect, attentiveness and politeness; and, at the same time, the requesting of diagnostic exams, referrals to medical specialists and the prescription of medicines. In their imaginary, the Basic Health Unit hinders their access to specialized care and doctors in this service do not know enough to meet the needs of people of different age groups and health problems, meaning that consulting with a specialist becomes more important. In practice, they encounter difficulties related to delays in being attended to and obtaining appointments with specialists, diagnostic exams and with the first come, first served appointment system, which is further limited by the number of places and treatment of specific groups on certain days. Conclusion: The practices in the care provided to the elderly in health services need to be reviewed to offer humanized and qualified care that can meet their needs. Health professionals and managers should consider the different characteristics of the elderly when approaching care.

Universidade Federal da Paraíba, Departamento de Enfermagem, Programa de Pós-Graduação em Enfermagem. João Pessoa, Paraíba, Brasil.

Keywords: Elderly. Delivery of Health Care. Primary Health Care. Health

Evaluation. 


\section{INTRODUCTION}

In Brazil, the first contact between the user and the health system is generally made through Basic Health Units (BHUs), which include Family Health Units (FHUs), where medical appointments and examinations are arranged and less complex procedures are carried out. If the health needs of the user exceed the capacity of these services, then the patient is referred to higher levels of care and attention ${ }^{1}$.

Ensuring the access of the general population to these levels of care and attention represents a challenge for the Brazilian Unified Health System (or SUS) ${ }^{2}$, especially because, with the rapid aging process observed in the population, together with the increased incidence of chronic diseases, the use of health services by elderly persons have tended to become more common and frequent. This means that managers and health professionals must not only deal with the difficulties that are already present, to offer universal and comprehensive access, that is equitable, longitudinal and coordinated, but must also adapt their services and train their health teams, based on the needs of the elderly, to offer care with quality $^{3}$. To achieve this, it is important to listen to the experiences of elderly and their opinions about what still needs to be improved ${ }^{4}$.

As the perception of a given phenomenon (in this case, services in health care units) is affected by the way in which the individual regards the reality that surrounds them, based on a system of values and beliefs, the Theory of Social Representations (TSR), created by Serge Moscovici, provides a tool for the interpretation of the results found ${ }^{5}$. This author highlights three dimensions for the establishment of social representations: Attitude (position of subjects in the light of the object of representation), images or field of social representation (meanings given to the objects through concrete content responsible for the organization of the field of representation) and information (knowledge of any one group about a social object).

The question is therefore asked: What are the general social representations of the elderly about care services? To respond to this issue, the main purpose of the present study was to identify the social representation of the elderly about services in the health care segment.

\section{METHOD}

An exploratory qualitative study was carried out in the city of João Pessoa, in the state of Paraíba, in Northeastern Brazil, in two FHUs and also at the Center for Integral Healthcare for the Elderly (or CAISI). The FHUs surveyed are both inserted in the same social and economic context, and offer several services to their users, including: medical and nursing appointments; dental appointments and other services, home visits, application of vaccines, checking of blood pressure and blood sugar levels, distribution of medication. They also have special groups to monitor high blood pressure and diabetes and for Community Therapy.

When they arrive, the elderly people go to reception, explain why they have come, and are then attended to in order of arrival. If they need to be referred to a specialist doctor, or require any kind of medical examinations, these arerequested through an employee (appointment scheduler) who books the appointments. The elderly person is then informed of the date of the appointment, either on the same day or at a later date, as this depends on the availability of places offered by the municipality for a given service.

The CAISI serves an average of 2,500 elderly people per month, in 16 different specialties (as referred by the FHU), offering dentistry, nutrition and physiotherapy treatment, as well as activities that help healthy aging, including Memory Groups, Socializing, Posture Education, Physical Education, Flute and Dance. When they arrive at the service, the elderly people give their names to the attendants, who then check to see if there has been any prior booking made by the health unit. They are then called by order of arrival.

A total of 238 elderly people were interviewed (119 at the FHU, and the other 119 at CAISI), comprising a non-random sample, selected based on convenience and delimited by the criterion of data saturation, 
which occurs when the data as accessed by the researcher displays redundancy, without the need to further expand the sample, as the information obtained is considered sufficient ${ }^{6}$. The following inclusion criteria were applied: Elderly people aged 60 or over; people who were attended at the same health service where the interview was conducted; those who did not have any cognitive deficit that would prevent the interviews from taking place; and acceptance of participation in the study. The Mini Mental State Exam (MMSE) was applied for cognitive appraisal, and eight elderly people who scored less than 27 points were excluded. In addition, 20 elderly people declined to participate, on the grounds of lack of interest.

The data were collected between January and May 2016, Monday to Friday, through a semi-structured interview, by a single interviewer who hadreceived prior training through lessons and theoretical training about this type of interview. The elderly people were individually approached in the waiting rooms of the CAISI and the FHUs, and then asked if they would be interested in taking part in the survey. If they said yes, they were invited to follow the researcher into a reserved room, made available by the service, where they were given further information about the goals of the research study, and also informed that they had the right not to participate in the study.

After meeting the criteria for inclusion and after signing a Free and Informed Consent Form (FICF) (or giving consent through their finger prints), the elderly people were invited to answer the question: "How would you evaluate the service you have received here?" The interview also included questions to characterize the interviewees: age, gender, level of schooling, marital status, and family income.

The statements were recorded and then fully transcribed, after which they were processed and analyzed using the Iramuteq software (Interface de
$\mathrm{R}$ pour les Analyses Multidimensionnelles de Textes et de Questionnaires), version 0.7 alpha 2. The group of interviews was divided into smaller sections of text by the software. These Text Segments (TS) are then subjected to the Descending Hierarchical Classification method (DHC) and also to the chisquared test $\left(\chi^{2}\right)$ to obtain the classes, which are established based on similarity of vocabulary as present in the declarations. An in-depth reading was made for each class, by two researchers, to interpret the statements and identify social representations.

This study was approved by the Research Ethics Committee of the Hospital Universitário Lauro Wanderley (the Lauro Wanderley University Hospital) (or HULW), protocol number 261/09 and CAAE: 0182.0.126.000-09. The individual statements were identified as subject 1 , subject 2 and so forth. To protect the identities of those working at the services considered, their professional classes were replaced by "health professional". The rest of the material was kept in its original version.

\section{RESULTS}

Among the elderly people interviewed, most were aged between 60 and 69 years old $(45.4 \%$ of the sample), were female $(74.8 \%)$, had a primary level education (56.3\%) and were married (42.0\%), with a family income of two Brazilian minimum wages (MWs) or more (76.4\%) (Table 1).

In terms of the analysis of the corpus by IRaMuTeQ, 1240 Text Segments (TS) were retained, corresponding to $94.44 \%$ of the 1313 TS of this study. Through DHC, the social representations of the level of service provided by the health services for elderly people were separated into five semantic classes, established based on their content. The program also identified the intersection and description of the classes (DHC) and created the dendogram of the classes of the corpus, as shown in Figure 1. 
Table 1. Social and demographic characteristics of the elderly people interviewed at the Family Health Units (FHUs) and at the Center for Integral Healthcare for the Elderly. João Pessoa, Paraíba, 2016.

\begin{tabular}{|c|c|c|}
\hline Variables & $\mathrm{n}$ & $\%$ \\
\hline \multicolumn{3}{|l|}{ Age } \\
\hline 60 to 69 ages & 54 & 45.4 \\
\hline 70 to 79 ages & 50 & 42.0 \\
\hline 80 or over ages & 15 & 12.6 \\
\hline \multicolumn{3}{|l|}{ Gender } \\
\hline Female & 89 & 74.8 \\
\hline Male & 30 & 25.2 \\
\hline \multicolumn{3}{|l|}{ Schooling } \\
\hline Illiterate & 14 & 11.8 \\
\hline Can read and write & 3 & 2.5 \\
\hline Primary Education & 67 & 56.3 \\
\hline High School Education & 24 & 20.2 \\
\hline Higher education & 11 & 9.2 \\
\hline \multicolumn{3}{|l|}{ Marital Status } \\
\hline Married & 50 & 42.0 \\
\hline Single & 14 & 11.7 \\
\hline Widowed & 44 & 37.0 \\
\hline Divorced & 7 & 5.9 \\
\hline Separated & 4 & 3.4 \\
\hline \multicolumn{3}{|l|}{ Family Income } \\
\hline$<$ one minimum wage & 4 & 3.4 \\
\hline One minimum wage* & 24 & 20.2 \\
\hline Two minimum wageor more & 91 & 76.4 \\
\hline
\end{tabular}

* The value of the minimum wage considered in the year of the research was equivalent to BRL 880.00. 


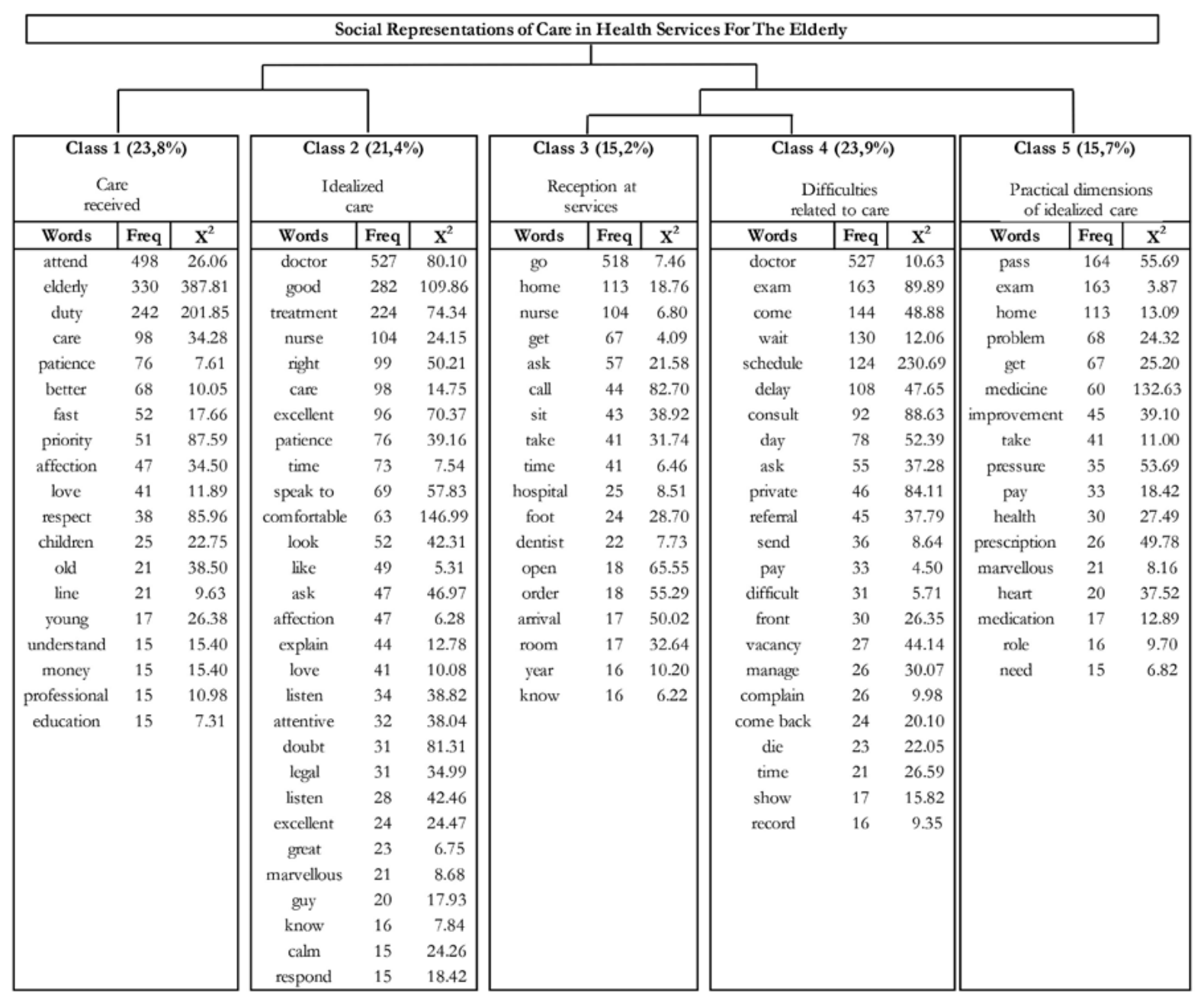

Figure 1. Dendogram of classes of social representations of services provided at health services for elderly people.

As Figure 1 shows, the software divided the classes into two main groups: one group was divided into two classes (1 and 2) and the other into one (5) which was in turn divided into two further classes ( 3 and 4). The first group (Classes 1 and 2) deals with affective aspects related to the services provided and, individually, each class presents one of the largest concentrations of TS of the whole corpus. The second group, represented by Class 5 , deals with practical aspects about the ideal form the elderly people feel the services provided should take. This was divided into two further classes, which shows how the services occur in reality, including current difficulties. Class 4 also has one of the highest proportions of TS, together with Classes 1 and 2.
To draw and construct the dendogram, the words with a chi-square $\left(\chi^{2}\right)$ value of 3.84 or over $(p<0.001)$ and frequency within classes of 14.45 or over, were selected. This cut-off point was established using the IRaMuTeQ software.

\section{DISCUSSION}

Among the elderly people interviewed, there was a prevalence of women, with a low income and poor level of schooling. The classes were established based on Social Representations Theory and current literature and are described below. 


\section{Class 1 -Service Received}

In general, the interviewees reported that they were well attended to and treated, and this concept was linked to that of talking, explaining, showing interest in the patient's health problems and their personal life, being attentive, being polite, and knowing how to listen:

“The health professionals are very attentive. They ask question, explain things, and resolve our concerns [...]" (Subject 11).

"I like this health professional a lot because they are attentive, polite, educated, and treat patients with loving care [...]" (Subject 150).

It was also confirmed that good service results in the common idea that the elderly have of these professionals, namely that they are mothers, angels, friends, family members, establishing bonds between them:

"This health professional is a real angel $[. .$.$] "$ (Subject 43).

"It is good, as we become a real family out here. They know our names, they know everything about us, the environment is like a real family [...]" (Subject 51)

"This health professional is my friend $[\ldots]$ " (Subject 65).

"This health professional is like a mother[...]"(Subject 144).

The relationship between health professional and user is beneficial to the extent that it establishes a relationship of bonding and trust, leading to greater participation in the actions for the promotion of health and prevention of health problems ${ }^{8}$.

\section{Class 2 - Idealized Service}

When asked about how they should be attended to when seeking out health services, the answers tend to show emotional aspects:
"Elderly people need a lot of love and attention. People need to have a lot of patience [...]” (Subject 29).

"Elderly people should be attended to with respect, patience, priority, love and understanding[...]"(Subject 51).

With advancing age, the thought of imminent death, the lack of social support through the loss of a partner, the departure of children from the home, or a lack of attention from relatives, even though the elderly people may still live with their families could all lead to greater emotional fragility in the elderly person?.

Other aspects mentioned by elderly people refer to the need to be treated quickly and given priority:

"An elderly person should be seen to quickly and get very good service. Elderly people shouldn't have to wait [...]"(Subject 138).

"I should be attended to first. Elderly people should have priority, but that doesn't happen here[...]"'(Subject 32).

The Law of the Elderly made a significant contribution to the defense of the rights of the elderly person. One of these rights is to priority treatment at Government institutes and private companies, which is not observed in many cases. However, when considering care priorities within health services, another factor to be borne in mind is the seriousness of the condition (and the overall need) of the user at the time ${ }^{10}$.

The service should take the needs of the elderly person into account:

"It's important to try to find out what their needs are. If it's medicine, or treatment, or something else. Often the proper attention isn't paid to the elderly person. [...]"'Subject 7).

Many of these needs are linked to the idea that the interviewees have about the elderly, namely that they are frail, ill, and about to die $^{11}$. Some respondents compare elderly people with children, due to their general state of frailty and dependence, and also 
because they are largely ignored and discriminated against by society in general.

The needs described as essential for people of advanced age, may also differ from those identified by the health professionals, which can affect adherence to the treatment established ${ }^{12}$. When their demands are not considered, and when there are barriers blocking access to, or the use of, services, there can be a greater distance between the services and the elderly people, as well as the non-accompaniment, by the health team, of the overall changes linked to the aging process, making them more prone to health risks (and other risks) and also to complications of the chronic diseases as already present ${ }^{13}$.

Many of the interviewees have chronic diseases (high blood pressure, cardiopathies, diabetes, arthrosis), which bring serious functional limitations which make it more difficult to get to the health services, and also making it difficult to remain seated, or stand up, for a long time. Some also take care of family members, which not only makes it more difficult for the patient to get to their health appointments, but also makes them distressed, due to the delays in receiving care.

Home visits, as established in the Family Health Program (FHP), benefit, first and foremost, elderly people who are unable to get to the health units, and who would be excluded from care. However, elderly people complain that such visits do not happen often enough:

"[...] She only comes to the house a few times[...]”(Subject 22).

"[...]When the elderly person is bedridden, there should be more visits[...]"(Subject 43).

The health professionals also report many difficulties in relation to home visits, such as an insufficient number of health professionals, a lack of transport, and problems reaching the most outlying areas, which has also been detected by a study carried out in Rio de Janeiro ${ }^{14}$.

\section{Class 3 - Reception at Services}

The reception recommended by the Brazilian Ministry of Health involves moments of listening to and displaying empathy and interest in the patient, and the identification of the social, psychological and biological needs of users, while following the principle of equity ${ }^{15}$. However, the perception of reception of many professional staff and students at the services is largely related to a bureaucratic service: Welcoming the users and then sending them elsewhere for treatment. They are often inflexible and do not take the needs of the clients into consideration ${ }^{16}$.

At the FHU surveyed, it was observed that the reception process is carried out by employees at the reception desks and also by Community Health Agents (CHA) who end up deciding who has priority of treatment. Normally the elderly people end up getting priority, but more urgent cases may be overlooked, and the individual advised to return another day, or even to seek alternative services, due to the lack of evaluation by a better qualified health professional. The Ministry of Health recommends that reception should be carried out by a nurse who, after listening to the needs of the user, can carry out interventions based on their own abilities or refer the patient on to other health professionals ${ }^{17}$.

At CAISI, consultations with health professionals are booked in advance at the FHU. When the patients arrive at the location, they wait their turn to be seen:

\footnotetext{
"It's on a first come, first served basis. You need to get there first, and then give your name. [...]"'(Subject 46).
}

"We arrive, sit on the chairs, then we ask the attendants for a form, and then they start calling out the names[...]" (Subject 123).

The users normally arrive early in the morning, so they can be one of the first to be served. If not they may end up not getting an appointment, in the 
case of the FHU. This reality was also reported in a survey carried out in the city of Rio de Janeiro $(\mathrm{RJ})^{18}$. One of the main complaints of elderly people relates to the lack of punctuality of the health professionals:

"I have waited up to five hours to be seen. The health professional books a time, and then arrives at a different time. We can waste a whole day here[...]"(Subject 226).

\section{Class 4 - Difficulties related to service}

The number of people attended to in the assessed services is limited. If the doctor orders an appointment with a specialist, or further diagnostic examinations, then the wait for medical care continues. Due to the limited number of time slots to book such procedures, many users have to wait months before they can be seen by a doctor.

Some elderly people even resort to private health services, sacrificing their pensions, and even request the help of family or friends, some even sell assets or take out loans with financial institutions to pay for medical examinations and appointments, so they do not need to wait to be attended to by the Government health system:

"I would rather pay for a private appointment than go to the FHP. Sometimes the medical professional doesn't turn up. When the medical professional does show up, then we can't a place. You put your name down, and it is often two or three months before we are referred[...]"(Subject 166).

Others mention the inefficiency of the system for scheduling appointments and medical examinations, or just a lack of care. In cases like this, the employees themselves advise the elderly people to seek private medical services:

"I went to book my transvaginal ultrasound. They said there were no places, and that I should get it done privately [...] (Subject 220).

A discussion of the real need to request these examinations is outside the scope of this paper. However, there are studies that warn about the indiscriminate practice of recommending medication and medical tests, pandering to the medical-industrial complex, and also referrals to specialists for individuals with health problems that could be handled by basic health care. This makes it difficult for those patients who truly require this technology to access it, and also presents an additional cost burden for the health system ${ }^{19}$. In addition, the scheduling of referrals to more complex services should consider the health needs of the user, rather than the order of request ${ }^{20}$.

Primary Health Care is the entry-point to the health system, to ensure greater efficiency and savings, and its importance is recognized by many healthcare managers who, in practice, are unable to implement it. At the same time, it is undervalued by the population who use the health system. Some possible causes for this are low resolutive capacity, political and financial prioritization of specialist care; lack of general practitioners; and the opening hours of the basic health units that do not consider the needs of their users ${ }^{21}$.

As PHC cannot function asa coordinator of care and a provider of solutions for the demands of elderly health care, such issues must be resolved in another form, disregarding the structure of the PHC as established by national guidelines for the implementation of the National Health Care Network. One of the ways in which we can impart greater legitimacy upon Basic Health Care (BHC) in relation to its users is to give greater independence to this level of care, thereby increasing its capacity to effectively manage regulatory processes, allowing health teams to gain direct access to the booking of medical appointments, and allowing doctors to have better communication with regulatory bodies, whenever necessary ${ }^{22}$.

Another issue to be addressed is the scheduling of the FHU service based on days for particular health issues or population groups. It is important that the treatment provided to priority groups for health care, as established by the MH (children, pregnant women, hypertensive patients, and people living with diabetes), is not morphed into actions that limit the access of other users to services ${ }^{23}$. The elderly people complain about the delay and lack of 
service at the FHUs, as they do not fit into such a schedule of needs. This situation was also described in a study carried out in the state of São Paulore

"They say today is the day for pregnant women, so they cannot attend to us. On the day for pregnant women, only they get seen[...]" (Subject 130).

Some elderly people confess that they resort to the use of family members and friends who are in some way linked to the services, in the hope of getting quicker treatment:

"As my son works here, I am seen to quickly[...]"(Subject 215).

"I only managed to book my bone densitometry because I have a friend who works at theFHP[...]" (Subject 250).

"It took me six months to have a medical examination. I spoke to the health professional, who said that in January I would be the first patient to be seen to[...]"(Subject 57).

In addition to all these difficulties, in many cases elderly people are sent to units far from their homes, requiring them to use public transport. This, apart from adding extra expense, may also cause an excessive physical burden. Many are referred from one place to another:

\footnotetext{
"You live in one district and near your home there is a laboratory that serves the area; however, they send you somewhere else, and you often have to take a bus. For medical appointments, they normally send you very far away [...]"(Subject 202).

"When I arrived, the health professional sent me to Tambaú for a tooth implant. When I got there, she wasn't there. On another day, the equipment was broken and they asked me to come back another day. So I came back, and there was no professional available. I never went back [...]” (Subject 3).
}

The choice of the referral service should bear the specific needs of the users in mind. This would include factors such as functional, cognitive, and financial limitations, which make travel difficult.
One must also consider whether these people have the means to access these locations, especially in the case of elderly people. This could be achieved, for example, through a search for service providers closer to the patient's residence and also an investigation of social networks of the elderly, to see if there is anyone who could take responsibility for accompanying them.

According to the employees of the FHUs studied, the choice of the referral service is only based on availability of places, regardless of location. This is because, if it were not performed in this way, access to medical care would be even more at risk, due to the reduced number of vacancies compared to the demand.

For booking medical appointments and diagnostic examinations, the National Regulation System (or SISREG) is used. This is an online system (employing a specific software system) that manages specialized outpatient and hospital resources at municipal, state and regional level. This computerized system has brought many benefits, including avoiding unnecessary travel to specialized services for booking appointments, as everything can be done online ${ }^{25}$.

However, some authors have described difficulties in using this system, which can help us understand some of the problems reported by the elderly in this study, including: absence of an access protocol number for services, definition of when the medical procedure is routine, priority, or urgent; inability of operator to use the system, leading to mistakes when filling in the requests; technical problems related to the program and Internet connections; and lack of specialists in certain areas ${ }^{26,27}$.

A need to improve the information about the operation and function of the system itself has also been noted (a lack of signage in the treatment room and a shortage of information about the procedures necessary to obtain prescriptions and book appointments was observed) and also referrals to other services. Information should be passed to the elderly using audible and appropriate language. At the same time, one must identify hearing deficiencies and low levels of education. 
One strategy to improve information, and to streamline and modernize service would be to make greater use of technology. Many developed countries deal with their users by telephone or e-mail. This is not a replacement for physical examination, but rather a way to provide guidance and answer queries. This also means that the user does need to go to the health unit just to find out whether their appointment has been arranged or if there is a doctor available to attend to the patient. In addition, the telephone can also be used by employees to remind the elderly patients about the dates and times of their appointments and examinations, which could reduce the rate of absenteeism and allow vacancies arising from cancellations to be properly utilized ${ }^{28,29}$.

Another complaint described by the elderly people interviewed is the need to first go to the FHU when booking an appointment with a medical specialist, as this is a major obstacle to getting treatment, which was also observed in a study carried out in the state of São Paulo ${ }^{30}$, or for a simple bureaucratic procedure to receive prescriptions for medication and referrals to specialist doctors, or to register whether treatment has been carried out:

"After entering the FHP, you go to the general practitioner, who books a time, and then you hand the time scheduled to the official appointment scheduler. One month, two months, three months, even a year. Anyone with a serious condition may die without even being attended to. The problem lies mainly with the FHP [...]"(Subject 125).

"Is it the prescription you want? They ask what the medication is, and that's all. They don't even give you attention, they couldn't care less. I just come to pick up my prescription [...] (Subject 30)

"On Friday I go to the FHPhealth professional to ask for a referral to the cardiologist [...]”(Subject 109).

The negative perception of elderly people with regard to the FHU is based on the lack of resolutive capacity of these services, due to difficulties of access to different levels of care, which breeds a lack of satisfaction and a lack of credibility in relation to the service, and therefore of the health service as a whole ${ }^{31}$.

\section{Class 5 -Idealized practical dimensions of the service}

The interviewees highlight the characteristics of the services provided, which are considered as representations, anchored to a doctor-centric culture, medicalization, and the compartmentalization of health services into specialities ${ }^{32}$ :

"Good service is requesting medical exams, and giving medication[...]” (Subject 217).

"I like it here because we have the specialties. There was a health professional who was good, and has now been transferred. The medication that he gave to me[...]"(Subject 131).

This is due to the biomedical model for health care, to which the population has been submitted, and which remains in the imaginary of users and also the practice of many health professionals, making its deconstruction extremely difficult ${ }^{33}$. The value given to health care based on specialized care is evident in some statements:

\footnotetext{
"The general practitioner (GP) needs to know a lot. You go to the urologist, it is for one specific thing. The same goes for the eye doctor, and the head doctor. Now, the general practitioner is for everything[...]" (Subject 3).

"To improve the service, we need specialists. In the past we had everything here, even heart specialists, it was really great. Now they have taken everything away, and put this other service in [...]"(Subject 131).
}

Another study carried out in Brazil showed the lack of recognition of Primary Health Care professionals, especially doctors, by the users. The training of these professionals should be one of the top priorities of the Government, because it increases the credibility of the population, who then have more trust in these services and their capacity to solve health problems ${ }^{34}$.

One limitation of the present study was the fact that it was carried out in health services in only one Brazilian municipal region, however, the results found 
reflect many of the problems with health services experienced by people in other parts of Brazil and in other countries with Universal Health Services, which feature primary health care as the basis of their health systems, as described throughout the article. Another limitation is that the perception of the users may have been influenced by their own social and economic context, the context within which the services are located, and the type of service received and expected (basic health care or specialized health care).

The fact that the interviews took place in the same location as treatment was received could also be a significant limitation. However, it was observed that most of the interviewees were willing to talk about the health care received, and the difficulties that they face (only 20 elderly people refused to participate in the survey), and considered the interviews as a place where they can speak and be heard. What may have contributed to this was the assurances provided regarding their confidentiality of their identity, the fact that the survey took place in a closed room (with only the elderly interviewee and the interviewer present), and the fact that it was carried out by a person unattached to the services ${ }^{35}$.

\section{CONCLUSION}

The study describes, as social representations, the fact that the elderly people associated good health care with being treated with respect, attention and politeness. In their opinion, health professionals should talk, explain, and show interest in their health problems and personal life. At the same time, they connected good service with the prescription of medication and medical tests, along with referrals to specialists, which reinforces the culture of giving greater value to the biomedical model of health care.

\section{REFERENCES}

1. Brasil. Ministério da Saúde, Conselho Nacional de Secretários Municipais de Saúde. O SUS de Aa Z: garantindo saúde nos municípios [Internet]. Brasília, DF: Ministério da Saúde; 2005 [acesso em 01 abr. 2018]. Disponível em: http://bvsms.saude.gov.br/bvs/publicacoes/sus_az_ garantindo_saude_municipios_3ed_p1.pdf
In the imaginary of those interviewed, the FHU represents more of an obstacle than a gateway to entering the health care system, as it hinders the obtaining of specialized health care. In addition to this meaning, which is often assigned to the FHU, there is the perception that the basic health care doctor does not have the knowledge to simultaneously deal with people from different age brackets and with different health problems, meaning that an appointment with a specialist is required.

In the locations surveyed, elderly people exhibited satisfaction with the care and service they received, at least with regard to the affective relationship with the staff. They all felt welcomed and well treated. At the same time, they complained about many aspects that need to be reviewed and improved, some specifically concerning the dynamics of the locations investigated, and others related to the function of the health system in general. Regardless of whether these problems are related to the system or the service, the solution to these problems must consider the Humanization Policy of the Brazilian Ministry of Health and also the International Protocols for User Care, especially those related to elderly people (Towards Age-friendly Primary Health Care).

It is also important to stress that the purpose of this study was not to specifically evaluate the health services studied, or even to assess the health professionals working there. These individuals should also be heard, to investigate the possible difficulties they face, which could result in further user dissatisfaction. In any case, it is hoped that these results contribute to modifying the viewpoint and practice of health professionals and managers, with regard to the services offered to elderly people, considering the specific characteristics of this age group, so that they may have a better chance of having their health problems resolved.

2. Oliveira DC, Cecilio HPM, Gomes AMT, Marques SC, Spindola T, De Pontes APM. A universalização e o acesso à saúde: consensos e dissensos entre profissionais e usuários. Cad Saúde Colet [Internet]. 2017 [acesso em 09 out. 2018];25(4):483-90. Disponível em: http://www.scielo. br/pdf/cadsc/v25n4/1414-462X-cadsc-25-4-483.pdf 
3. World Health Organization. Summary. World report on ageing and health [Internet].Geneva: WHO; 2015 [acesso em 09 out. 2018]. Disponível em: http://apps. who.int/iris/bitstream/10665/186468/1/WHO_ FWC_ALC_15.01_eng.pdf?ua=1

4. World Health Organization. Towards age-friendly primary health care [Internet]. Geneva: World Health Organization; 2004 [acessoem09 out. 2018]. Disponívelem: http://apps.who.int/iris/ bitstream/10665/43030/1/9241592184.pdf

5. Moscovici S. Representações Sociais: investigações em Psicologia Social. 7ed. Rio de Janeiro: Vozes; 2010.

6. Denzin NK, Lincoln YS, editors. Handbook of qualitative research. Thousand 4th.Oaks: SagePublications; 2011.

7. Camargo BV, Justo AM. Tutorial para uso do software de análise textual IRAMUTEQ [Internet]. 2013 [acesso em 09 out. 2018]. [S.1.]: [S.n.]. Disponível em: http://www.iramuteq.org/documentation/fichiers/ tutoriel-en-portugais

8. Soares JDL, de Araujo LFS, Bellato R, Petean E. Tecitura do vínculo em saúde na situação familiar de adoecimento crônico. Interface (Botucatu)[Internet]. 2016 [acesso em 09 out. 2018];20(59):929-40. Disponível em: http://www. scielo.br/scielo.php?script $=$ sci_arttext\&pid=S141432832016000400929\&lng=pt\&tlng=pt

9. Almeida MASO, Lemesa AG, do Nascimento VF, da Fonseca PIMN, da Rocha EM, Liba YHAO, et al. Fatores de risco associados à depressão em idosos no interior de Mato Grosso. Rev Baiana Saúde Pública [Internet]. 2015 [acesso em 09 out. 2018];39(3):62741. Disponível em: https://www.researchgate. net/publication/295541043_Fatores_de_risco_ associados_a_depressao_em_idosos_no_interior_ de_Mato_Grosso

10. Silva KM, Dos Santos SMA. A práxis do enfermeiro da estratégia de saúde da família e o cuidado ao idoso. Texto Contexto Enferm [Internet]. 2015 [acesso em 03 abr. 2019];24(1):105-11. Disponível em: https:// www.redalyc.org/html/714/71438421013/

11. Daniel F, Antunes A, Amaral I. Social representations of ageing. AnálPsicol[Internet]. 2015 [acesso em 09 out. 2018];33(3):291-301. Disponível em: http://publicacoes. ispa.pt/index.php/ap/article/view/972/pdf

12. Voigt I, Wrede J, Diederichs-Egidi H, Dierks M, JuniusWalker U. Priority Setting in General Practice: Health Priorities of Older Patients Differ from Treatment Priorities of Their Physicians. CroatMed J [Internet]. 2010 [acesso em 09 out. 2018];51:483-92. Disponível em: http://dx.doi.org/10.3325/cmj.2010.51.483
13. Martins LB, D'Avila OP, Hilgert JB, Hugo FN. Atenção Primária a Saúde voltada as necessidades dos idosos: da teoria à prática. Ciênc Saúde Colet [Internet]. 2014 [acesso em 03 abr. 2019];19(8):3403-16. Disponível em: https://www.scielosp.org/scielo.php?pid=S141381232014000803403\&script=sci_abstract

14. Kebian LVA, Acioli S. A visita domiciliar de enfermeiros e agentes comunitários de saúde da Estratégia Saúde da Família. RevEletrEnferm[Internet]. 2014 [acesso em 18 mar. 2019];16(1):161-9. Disponível em: https://www. revistas.ufg.br/fen/article/view/20260/16455

15. Brasil. Ministério da Saúde, Secretaria de Atenção à Saúde, Departamento de Atenção Básica. Envelhecimento e saúde da pessoa idosa. Brasília,DF: Ministério da Saúde; 2007.

16. Arruda CAM, Bosi MLM. Satisfação de usuários da atenção primária à saúde: um estudo qualitativo no Nordeste do Brasil. Interface (Botucatu)[Internet].2017 [acesso em 09 out. 2018];21(61):321-32. Disponível emhttp://www. scielo.br/scielo.php?script $=$ sci_arttext\&pid=S1414$32832017000200321 \& \operatorname{lng}=$ en\&nrm $=$ iso $/ \& \operatorname{lng}=$ pt

17. Brasil. Ministério da Saúde. Secretaria de Atenção à Saúde, Departamento de Atenção Básica. Acolhimento à demanda espontânea [Internet]. Brasília, DF: Ministério da Saúde; 2011 [acesso em 09 out. 2018]. Disponível em: http://189.28.128.100/dab/ docs/publicacoes/geral/miolo_CAP_28.pdf

18. Campos RTO, Ferrer AL, da Gama CAP, Campos GWS, Trapé TL, Dantas DV. Avaliação da qualidade do acesso na atenção primária de uma grande cidade brasileira na perspectiva dos usuários. Saúde Debate [Internet]. 2014 [acesso em 09 out. 2018];38(Esp.):25264. Disponível em: http://www.scielo.br/pdf/sdeb/ v38nspe/0103-1104-sdeb-38-spe-0252.pdf

19. Cuentro VS, Andrade MA, Gerlack LF, Bós AJG, Silva MVS, Oliveira AF. Prescrições medicamentosas de pacientes atendidos no ambulatório de geriatria de um hospital universitário: estudo transversal descritivo. Ciênc Saúde Colet[Internet]. 2014 [acesso em 09 out. 2018];19(8):3355-64. Disponível em: http://www.scielo.br/scielo.php?script=sci_ arttext\&pid=S1413-81232014000803355\&lng=en

20. Santos L. Região de saúde e suas redes de atenção: modelo organizativo-sistêmico do SUS. Ciênc Saúde Colet [Internet]. 2017 [acesso em 03 abr. 2019];22(4):1281-9. Disponível em: https://www.scielosp.org/scielo.php?pid=S1413$81232017000401281 \&$ script=sci_arttext\&tlng=pt\# 
21. Bousquat A, Giovanella L, Campos EMS, de Almeida PF, Martins CL, Mota PHS, et al. Atenção primária à saúde e coordenação do cuidado nas regiões de saúde: perspectiva de gestores e usuários. Ciênc Saúde Colet [Internet]. 2017 [acesso em 03 abr. 2019];22(4):114154. Disponível em: http://www.scielo.br/pdf/csc/ v22n4/1413-8123-csc-22-04-1141.pdf

22. Cecilio LCO, Andreazza R, Carapinheiro G, Araújo EC, de Oliveira SA, Andrade MGG, et al. A Atenção Básica à Saúde e a construção das redes temáticas de saúde: qual pode ser o seu papel?. Ciênc Saúde Colet [Internet]. 2012 [acesso em 03 abr. 2019];17(11):28932902. Disponível em: http://www.scielo.br/pdf/csc/ v17n11/v17n11a05.pdf

23. Tesser CD, Norman AH. Repensando o acesso ao cuidado na Estratégia Saúde da Família. Saúde Soc [Internet]. 2014 [acesso em 07 jul. 2018];23(3):86983. Disponível em: https://www.scielosp.org/scielo. php?pid=S0104-12902014000300869\&script $=$ sci_ arttext\&tlng=pt

24. Gomide MFS, Pinto IC, Bulgarelli AF, dos Santos ALP, Gallardo MPS. User satisfaction with primary health care: an analysis of access and care. (Botucatu) [Internet]. 2018 [acesso em 09 out. 2018];22(65):387-98. Disponível em: http://go galegroup.ez15.periodicos. capes.gov. $\mathrm{br} / \mathrm{ps} / \mathrm{i} \cdot \mathrm{do}$ ?\&id=GALE $\mid$ A $536243883 \& \mathrm{v}=2.1 \& \mathrm{u}=$ capes\&it $=\mathrm{r} \& \mathrm{p}=\mathrm{AONE \& sw}=\mathrm{w} \#$

25. Brasil. Ministério da Saúde, Conselho Nacional de Saúde. Manual de implantação de complexos reguladores . Brasília, DF: Ministério da Saúde; 2006.

26. Pinto JR, Carneiro MGD. Avaliação do agendamento online de consultas médicas especializadas através da central de regulação do SUS. Saúde Colet [Internet]. 2012 [acesso em 03 abr. 2019];9(58):123-8. Disponível em: https://www. redalyc.org/pdf/842/84225063005.pdf

27. Peiter CC, Lanzoni GMM, de Oliveira WF. Regulação em saúde e promoção da equidade: o Sistema Nacional de Regulação e o acesso à assistência em um município de grande porte. Saúde Debate [Internet]. 2016 [acesso em 03 abr. 2019];40(111):63-73. Disponível em: https://www.scielosp.org/scielo.php?pid=S0103$11042016000400063 \&$ script $=$ sci_arttext

28. Perron NJ, Dao MD, Righini NC, Humair JP, Broers B, Narring F, et al. Text-messaging versus telephone reminders to reduce missed appointments in an academic primary care clinic: a randomized controlled trial. BMC Health Serv Res [Internet] 2013 [acesso em 03 abr. 2019];13(125):2-7. Disponível em: https://bmchealthservres.biomedcentral.com/ articles/10.1186/1472-6963-13-125
29. Campbell JL, Fletcher E, Britten N, Green C, Holt TA, Lattimer $\mathrm{V}$, et al. Telephone triage for management of same-day consultation requests in general practice (the ESTEEM trial): a cluster-randomised controlled trial and cost-consequence analysis. Lancet [Internet]. 2014 [acesso em 03 abr. 2019];384:1859-68. Disponível em: https://www.sciencedirect.com/science/article/pii/ S0140673614610588

30. Marin MJS, Marchioli M, Moracvick MYAD. Strengths and weaknesses of the care delivered in the traditional Primary Healthcare Units and Family Healthcare Strategy units in the perspective of users. Texto Contexto Enferm [Internet]. 2013 [acesso em 07 jul. 2018];22(3):780-8. Disponível em: http://www. scielo.br/pdf/tce/v22n3/v22n3a26.pdf

31. Protasio APL, Silva PB, Lima EC, Gomes LB, Machado LS, Valença AMG. Evaluation of the reference and counter-reference system based on the responses of the Primary Care professionals in the first External Evaluation cycle of PMAQ-AB in the state of Paraíba. Saúde Debate [Internet]. 2014 [acesso em 07 jul. 2018];38(Esp.):209-20. Disponível em: http://www.scielo.br/pdf/sdeb/v38nspe/0103-1104sdeb-38-spe-0209.pdf

32. Ramos-Morcilloa AJ, Ruzafa-Martíneza M, Fernández-Salazarb S, Del-Pino-Casado R. ExpectationsanduserexperiencesofolderRoma women with health services in primary care. AtenPrim [Internet]. 2015 [acesso em 07 jul. 2018];47(4):2139. Disponível em: https://www.sciencedirect.com/ science/article/pii/S0212656714002285?via\%3Dihub

33. Melo SCC, de Santana RG, dos Santos DC, Alvim NAT. Práticas complementares de saúde e os desafios de sua aplicabilidade no hospital: visão de enfermeiros. RevBrasEnferm [Internet]. 2013 [acesso em 07 jul. 2018];66(6):840-6. Disponível em: https:// www.redalyc.org/html/2670/267029915005/

34. Arantes LJ, Shimizu HE, Merchán-Hamann E. Contribuições e desafios da Estratégia Saúde da Família na Atenção Primária à Saúde no Brasil: revisão da literatura. Ciênc Saúde Colet [Internet]. 2016 [acesso em 03 abr. 2019];21(5):1499-1509. Disponível em: https://www.scielosp.org/scielo.php?pid=S1413$81232016000501499 \&$ script $=$ sci_arttext\&tlng=en

35. MoimazI SAS, Marques JAM, Saliba O, Garbin CAS, Zina LG, Saliba NA. Satisfação e percepção do usuário do SUS sobre o serviço público de saúde. Physis[Internet]. 2010 [acesso em 03 abr. 2019];20(4):1419-40. Disponível em:https://www. scielosp.org/pdf/physis/2010 